\title{
RESTORATIVE JUSTICE: BRINGING JUSTICE FOR CRIME VICTIMS?
}

\author{
PN Makiwane \\ BA BProc LLB LLM LLD \\ Associate Professor, Department of Public Law \\ Walter Sisulu University
}

\begin{abstract}
SUMMARY
To date, South Africa's criminal justice system has been about crime and the punishment of offenders, and not about redress for crime victims. This can be ascribed to the nature of a criminal system that perceives crime to be a matter between the State and the accused, with the victim playing the marginal role of a witness. The retributive nature of our criminal justice has played a crucial role in the marginalization of the very person who was victimized, namely the crime victim. A number of countries have recently developed practices of restorative justice and therapeutic jurisprudence that have introduced an all-inclusive justice system that allows for participation by offenders, crime victims, their family members, the community and the State. Sadly, our country has been but tentative in its acceptance of restorative justice processes, with only a few thousands of individuals having benefitted from it since its inception. Although restorative justice is acclaimed as a system that allows for meaningful participation of victims in criminal processes, the author argues that the system favours mostly offenders, young offenders in particular, and is applied in respect of minor offences. For serious crimes, courts have been reluctant to embrace restorative justice processes, preferring to revert to the retributive system which is believed to have failed in reducing the crime rate in any country. In this article the author develops the idea that a lukewarm reception of restorative processes is detrimental to the administration of justice. It defeats the very purpose of victim involvement in the criminal justice system, and deprives the crime victim of the very benefits restorative justice is acclaimed for, namely healing and satisfaction.
\end{abstract}

\section{$1 \quad$ INTRODUCTION}

The South African criminal justice system, as with most other jurisdictions, is under pressure. Prison overcrowding, rising case loads, recidivism and crowded court dockets ${ }^{1}$ are some of the problems that contribute to the strain. To ease the problem of overcrowding, for example, the presidential prerogative to pardon prisoners is often exercised, sometimes to the prejudice of crime victims. ${ }^{2}$ Combined with the application of the parole

Schmid "Restorative Justice: A New Paradigm for Criminal Justice Policy" 200234 Victoria University of Wellington LR 91 .

2 Gromet and Darley "Retributive and Restorative Justice: Importance of Crime Severity and Shared Identity in People's Justice Responses" 2009 61(1) Australian Journal of 
system, ${ }^{3}$ a number of people who would otherwise be in jail are then released into their communities. Most of the criminals released in this way are on record as having re-offended soon after release. ${ }^{4}$

According to Freiberg, these problems resulted in the growing frustration with the traditional retributive system, which is considered to be ineffective, slow, outdated and, more importantly, showing little or no regard for the interests of crime victims. ${ }^{5}$ Although most authors acknowledge the destructive nature of imprisonment ${ }^{6}$ in particular, effective alternatives to imprisonment are limited. ${ }^{7}$ The limitation is exacerbated by the realization that restorative justice, a new model that is intended to facilitate victim participation in criminal processes, is not effective with recidivists and those who have committed very serious crimes. ${ }^{8}$

Some crime victims and societies feel that the criminal justice system is soft on crime. ${ }^{9}$ Consedine ${ }^{10}$ comments that there are many alternatives that are "effective, non-violent and cheaper". He goes on to say that offenders do not require imprisonment; instead, they require "patience, skill, and a whole new mind-set to enable their development". "This supports the general view held by most researchers who reject traditional retributive responses to crime, namely that restorative justice is beneficial to the interests of both offenders and victims of crime. ${ }^{12}$ Restorative responses to crime, ${ }^{13}$ which take into consideration not only the interests of offenders and the community, but those of the victims of crime as well, have been adopted in South Africa through various programmes. These measures include victim-

Psychology 50-57, observe that "focus on punitiveness has led to a number of well-known societal problems, including the overcrowding and the expense of the prison system, the solidifying of prison inmates' criminal identities and the exclusion of victims from their own justice processes".

3 Mujuzi "Unpacking the Law and Practice Relating to Parole in South Africa" 2011 Potchefstroom Electronic LJ 30.

4 Wright "Restorative Justice from Punishment to Reconciliation - The Role of Social Workers" 1998 6(3) European Journal of Crime, Criminal Law and Criminal Justice 267276.

5 Freiberg "A Post-Adversarial and Post-Inquisitorial Justice: Transcending Traditional Penological Paradigms" Faculty of Law, Monash University, Legal Studies Research Paper No 2010/1 1 http://papers.ssrn.com/s13/papers/cfm?abstract_id=1609468 (accessed 2012 12-26).

$6 \quad$ Wright 1998 6(3) European Journal of Crime, Criminal Law and Criminal Justice 267.

7 Dissel "Alternative Sentencing in South Africa" 19972 http://www.csvr.org.za/ articles/artsdiss2.htm (accessed 2014-01-15), argues that courts are reluctant to make use of new sentencing options because they do not consider correctional supervision, eg, to be sufficient punishment.

8 Snyman Criminal Law 5ed (2008) 22.

$9 \quad$ Marshall Restorative Justice: An Overview (1999) 26.

10 Consedine Restorative Justice: A Light in Darkness Paper Presented at the ICCPPC World Congress Mexico City 13 September 19991.

11 Ibid.

12 Eg, Skelton "Restorative Justice: A Contemporary South African Review" 200821 Acta Criminologica 37; and McElrea "A New Model of Justice" in McElrea and Brown (eds) The Youth Court in New Zealand: A Model for Justice (1993) 27.

13 Brunk "Restorative Justice and Philosophical Theories of Criminal Punishment" in Hadley (ed) The Spiritual Roots of Restorative Justice (2001) 31-56. 
offender mediation, ${ }^{14}$ family-group conferencing $^{15}$ and victim-support services. $^{16}$

The study on which this article reports, explored the literature to determine the extent to which restorative justice, beneficial as it may be, responds to the needs of both the offender and the victim in the South African context. The author advocates for the aggressive application of restorative justice processes by the police, prosecutors and the courts for the benefit of crime victims.

\section{RESTORATIVE JUSTICE DESCRIBED}

Restorative justice is a recent development in criminal justice that has emerged in the last three decades, notably in New Zealand and Australia. South Africa has, with a few other jurisdictions, ${ }^{17}$ embraced this newly-found system of response to crime. ${ }^{18}$ It is an approach to justice that allows crime victims, offenders, their families and community representatives to address the harm caused by the crime. ${ }^{19}$ Umbreit describes it as a victim-centred response to crime, ${ }^{26}$ a view that is shared by most authors. ${ }^{21}$ The United Nations describes restorative justice as:

"[A]ny process in which the victim and the offender, and, where appropriate, any other individuals or community members affected by a crime, participate together actively in the resolution of matters arising from the crime, generally with the help of a facilitator. Restorative processes may include mediation, conciliation, conferencing and sentencing circles".

Reference is always made to "prospects of participation" by crime victims. Restorative justice has, as a result, generated great interest among those who believe that retributive justice has failed to achieve the goals for which it was introduced. Although it enjoys strong support from those who seek alternatives to retributive justice, it has not been adequately or fully embraced by the general public or even the courts. As Skelton puts it:

14 See Eriksson "Victim-Offender Mediation in Sweden and South Africa" 2009 www.essays. se/essays/3070005eb9/ (accessed 2014-04-07).

15 Skelton and Frank "Conferencing in South Africa: Returning to our Future" in Morris and Maxwell Restorative Justice for Juveniles: Conferencing, Mediation \& Circles (2001) 103119.

16 Faull and Mputhing "Victim Support" 2007 http://issafrica.org.crimehub/uploads/CICH-6.pdf (accessed 2014-04-03).

17 Eg, Canada and the United States of America.

18 As Skelton and Batley "Restorative Justice: A Contemporary South African Review" 2008 21 Acta Criminologica 39, note: "Endorsement of the concept in [South African] policy documents of government came early in the Welfare White Paper (1996), the National Crime Prevention Strategy (1996) and several reports issued by the South African Law Reform Commission."

19 Skelton and Batley 200821 Acta Criminologica 38

20 Umbreit Family Group Conferencing: Implications for Crime Victims University of Minnesota Centre for Restorative Justice \& Peace-making (2000) 1.

21 Eg, Schmid 200234 Victoria University of Wellington LR 91; and Skelton and Batley 2008 21 Acta Criminologica 39.

22 United Nations Office on Drugs and Crime Handbook on Restorative Justice Programmes (2006) 100. 
"[A] visit to any magistrate's court, or indeed High Court, in the country, will provide evidence that the current justice system in the criminal courts rarely reflects restorative justice. The system is overwhelmingly adversarial and punitive. It may be argued that it has actually become increasingly punitive during the past decade.

The people's desire for retribution remains deeply rooted, especially among those who have been victims of serious crimes, such as murder, rape and robbery.

While the punishment of criminals is not the primary goal of restorative justice, this process nevertheless does not exclude punishment altogether. ${ }^{24}$ The focus is on the accused accepting responsibility, ${ }^{25}$ and the expected outcome is that the accused will refrain from future criminal activity. ${ }^{26}$ It encourages dialogue between the offender and the victim, and facilitates the healing process for the crime victim. ${ }^{27}$ Restorative justice is a system that is based on a theory of justice that considers crime and wrongdoing to be an offence against an individual or community, rather than against the State. ${ }^{28}$ Its emphasis is on repairing the damage caused by the offender, who must take full responsibility for his/her actions. This distinction has promoted the view that restorative justice and retributive justice are mutually exclusive. However, in practice, restorative justice does not exclude punishment, but merely places emphasis on aspects such as reconciliation and prevention of future offending by the affected person. ${ }^{29}$

According to Corrective Services $\mathrm{NSW}^{30}$ restorative justice brings together those parties who have a stake in a particular offence, in order for their addressing the harm, the needs and obligations of the victim, as part of a healing process. It is supposed to put the person most affected by the crime, the victim, at the centre of the process. The process:

"enables stakeholders to cooperate and come to a mutual agreement on sentences, and upon appropriate outcomes at different stages of the criminal process. Its effectiveness depends predominantly upon the sincerity of the victim and the offender in the restoration of harm".

23 Skelton "Tapping Indigenous Knowledge: Traditional Conflict Resolution, Restorative Justice and the Denunciation of Crime in South Africa" 2007 Acta Juridica 235.

24 Gromet and Darley 2009 61(1) Australian Journal of Psychology 52. Also see Von Bonde Redress for Victims of Crime in South Africa: A Comparison with Selected Commonwealth Jurisdictions LLD Thesis Faculty of Law NMMU October 2006 6, who comments: "While restorative justice represents a new direction in criminal justice, its objectives are not necessarily different from those of traditional criminal justice systems."

25 Van Ness and Strong Restoring Justice (1997) 42.

26 Muntingh and Monaheng "Family Matters: How Young Offenders' Families Engage in Restorative Justice" 19983 http://www.ccr.uct.ac.za/archive/two/7_3/p13.html (accessed 2013-10-15).

27 Schmid 200234 Victoria University of Wellington LR 91.

28 Koen "The Antinomies of Restorative Justice" 2007 Acta Juridica 248.

29 Daly "Revisiting the Relationship between Retributive and Restorative Justice" in Strang and Braithwaite Restorative Justice: Philosophy to Practice (2001) 33-54.

30 Corrective Services: NSW "Restorative Justice" 20112 http://www.correctiveservices. nsw.gov.au/information/restorative-justice (accessed 2013-01-10).

31 Justice Action "Restorative Justice: Creating a Safer Society" 16 March 20122 mhtml:file://RestorativeJustice-Wikipedia, the free encyclopedia.mht (accessed 2013-0129). 


\section{THE MERITS AND DEMERITS OF RESTORATIVE JUSTICE}

\section{Introduction}

Restorative justice is a novel approach to crime that has been acclaimed in most quarters ${ }^{32}$ as a development that will answer to the ills of the retributive form of justice. There are, however, clear indications that restorative justice cannot be used in isolation, and that the retributive aspect will always be found within restorative justice processes. The two approaches to justice are not mutually exclusive. ${ }^{33}$ Like retribution, restorative justice offers both merits and demerits. Below is a discussion of some of the observations:

\section{Merits of the restorative process}

Restorative justice entails the use of various schemes that may achieve different goals. ${ }^{34}$ Among these schemes are family-group conferencing and victim-offender mediation. These schemes have one aspect in common: They bring the victim and the offender face to face, creating an opportunity for the offender to realize the harm he/she has caused and, if he/she so desires, to apologize. ${ }^{35}$ The victim is free to ask a question such as: "Why did you do it?" Such a question puts the victim in a position to better understand the circumstances under which the harm occurred, and possibly extend forgiveness ${ }^{36}$ to the offender. Even before the parties engage in restorative processes, the offender must acknowledge guilt. ${ }^{37}$ The offender must take full responsibility for what happened. The victim must do the same or at least accept what occurred. This interaction, it is alleged, promotes healing and satisfaction for both parties. ${ }^{38}$

Commenting on responsibility, Henderson ${ }^{39}$ explains: "Taking individual responsibility for the experience may help the victim to find meaning. Responsibility means being the uncontested author of an event or thing". He elaborates:

32 See, eg, the number of articles which are pro-restorative justice in McLaughlin, Fergusson, Hughes and Westmarland Restorative Justice: Critical Issues (2003).

33 This is implied in the statement by Brunk in Hadley (ed) The Spiritual Roots of Restorative Justice 35, that restorative justice has taken its place alongside the competing theories of approaches to crime and punishment: retributive, utilitarian, rehabilitative.

34 Tinsley and McDonald "Is There Any Other Way? Possible Alternatives to the Current Criminal Justice Process" 201117 Canterbury LR 192.

35 Wright 1998 6(3) European Journal of Crime, Criminal Law and Criminal Justice 269-270.

36 Skelton and Batley 200821 Acta Criminologica 39, remark that restorative justice "is not forgiveness, the theory does not require forgiveness, nor does a restorative process seek it".

37 See S v M (Centre for Child Law Amicus) 2007 BCLR 1312 (CC).

38 New Zealand Ministry of Justice "Victim Satisfaction with Restorative Justice: A Summary of Findings" September 20111 http://www.justice.govt.nz/publications-global/v/victimsatisfaction-with-restorative-justice.htm (accessed 2014-01-14).

39 Henderson Restorative Justice (1985) 961. 
"Assuming responsibility for a traumatic experience is a process requiring an assertion or reassertion of control in one's life. Responsibility initially requires an individual to accept that an event occurred. But a frequent first reaction to traumatic experience is a denial that the event occurred at all, in part to avoid the death anxiety produced, but also in part to avoid acknowledgement that such a horrible thing could be a part of life".

Until the victim acknowledges the traumatic experience as his/hers alone, for example, that he/she was raped or mugged, the victim, according to Lifton, ${ }^{41}$ "is virtually powerless to be free from the rapist or mugger, or to take responsibility for, and thereby reassert control over, the event and the direction of [his]/her life".

If crime victims could take personal responsibility, instead of apportioning blame or finding fault with others, as is usually the case, and, if society could do the same instead of blaming the victim, the taking of responsibility by the offender would be facilitated. ${ }^{42}$ Furthermore, if the victim is blamed, or other people fail to accept the victim's experience, this may further isolate the victim from the experience, thereby blocking a successful resolution of the problem. The offender also has to take responsibility for his/her actions before the healing process can begin. ${ }^{43}$

When the offender acknowledges guilt, he/she is spared the pain of appearing before court to stand trial. The victim is also spared the trauma of reliving his/her pain in court, and of being subjected to rigorous crossexamination in which sordid details and insinuations about his/her personal life may be exposed. ${ }^{44}$ The diversionary nature of pre-trial family-group conferencing and victim-offender mediation, both being examples of restorative processes, keep young offenders and their victims away from the courts. ${ }^{45}$ The offender remains in the community, and can therefore attend to personal affairs. ${ }^{46}$ Unfortunately, the process is permitted under controlled conditions: For certain offences, diversion can only follow after the court process has taken its course. It is submitted that this process is biased in favour of offenders who, it seems, must be kept out of prison at all costs, irrespective of the negative impact the crime has had on the victim. Victims may, in some cases, be allowed to make victim-impact statements at various stages before the trial is concluded.

There are benefits for victims that can be derived from the use of restorative justice processes. According to Shapland, ${ }^{47}$ research results

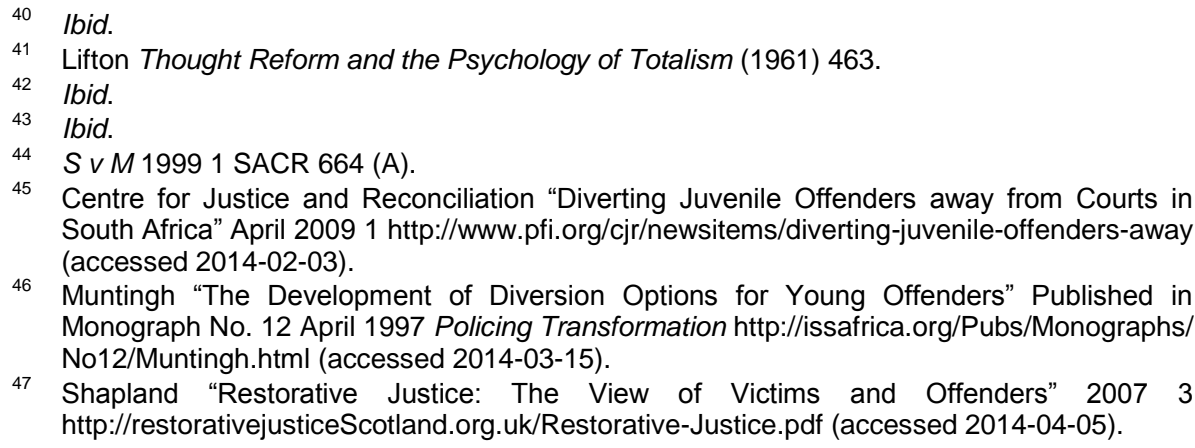

46 Muntingh "The Development of Diversion Options for Young Offenders" Published in Monograph No. 12 April 1997 Policing Transformation http://issafrica.org/Pubs/Monographs/ No12/Muntingh.html (accessed 2014-03-15).

47 Shapland "Restorative Justice: The View of Victims and Offenders" 20073 http://restorativejusticeScotland.org.uk/Restorative-Justice.pdf (accessed 2014-04-05). 
indicate that, compared with traditional justice programmes, restorative justice programmes provide higher levels of victim-offender satisfaction with the processes and outcomes, and a greater likelihood of successful restitution. He adds that these programmes have reduced fear among victims and decreased the frequency of further re-offending. ${ }^{48}$ The associated aspects of healing, reconciliation, and reparation in the form of restitution or compensation are all benefits for crime victims.

\section{Demerits of the restorative process}

Restorative justice processes, it is assumed, allow for victim participation in the criminal process. Such "participation", however, occurs at the margins of the process. The victim is, it is submitted, not so much at the centre of the process as is generally believed. The process is nevertheless intended to accommodate his/her interests. "Participation" would assume that the victim is involved during the major stages of the trial, and not outside the trial process in pre-trial discussions. This is a rare occurrence in South Africa but it is open for consideration.

Family-group conferencing and victim-offender mediation in practice are means of keeping the offender, not the victim, away from the trial process. If the accused admits guilt, he/she is allowed into the diversion process, which will bring him/her into direct contact with the victim before the envisaged trial takes place. In this sense, there can be no claim of victim participation in the criminal process itself.

It is submitted that "victim participation" is an inevitable by-product of the process. Although not clearly articulated, the process was introduced out of concern that crime victims were marginalized. The concern remains: the process inadvertently allowed itself to be diverted and puts offenders at the centre. Putting offenders at the centre of the criminal process is a result of the obsession with reducing over-crowding in prisons, addressing reoffending and keeping juvenile offenders out of the court system. ${ }^{49}$ In New Zealand, a pioneer in the area of family-group conferencing, the Children, Young Persons and Their Families Act, ${ }^{50}$ introduced in sections 5 to 13 the following principles of youth justice:

(a) Keeping young people [offenders] out of the criminal justice system; and

(b) keeping young people in the community.

Since the introduction of the Victims' Rights Act, ${ }^{51}$ these principles have, in New Zealand, been extended to apply to adults as well. ${ }^{52}$ The above principles apply equally under the South African legal system.

48 Ibid.

49 One of the stated purposes of the Child Justice Act 75 of 2008 is "diverting of criminal matters [involving children] away from the criminal justice system". This diversion applies where the offender is a child; it is not the case where the victim is a child and the offender an adult.

50173 of 1989

5139 of 2002.

52 However, the courts in practice restrict the use of these processes for less serious crimes. 
There is no question that the person who benefits most from the process is the offender: If he/she admits guilt, thereby accepting responsibility for his/her actions, and offers restitution or compensation, he/she may avoid imprisonment. In serious cases, he/she may receive a reduced sentence. ${ }^{53}$ That parties participate voluntarily in the process is nothing but a myth. Offenders obviously stand to gain from admitting guilt, and would in all probability opt for diversionary processes. If the offender takes responsibility for his/her actions, he/she may receive a reduced punishment. In most cases, he/she will go back to the community and even resume his/her routine chores, such as employment. Crime victims, on the other hand, will not necessarily want to participate, but subtle coercion by the police and prosecutors leaves them with no choice other than to cooperate. Admittedly, in some cases the victim stands to gain in the form of restitution or compensation. The victim whose television set was stolen may have the item returned, or get compensated to the extent of its value.

Compensation and restitution are, however, catered for even if the matter goes to trial. Section 297(1) of the Criminal Procedure Act, ${ }^{54}$ with respect to compensation, provides as follows:

“(1) Where a court convicts a person of any offence, other than an offence of which any law provides a minimum punishment, the court may in its discretion - (a) postpone for a period not exceeding five years the passing of a sentence and release the person concerned - (i) on one or more of the conditions, whether as to - (aa) compensation; (bb) the rendering to the person aggrieved of some specific benefit or service in lieu of compensation for damage or pecuniary loss; [...] (4) Where a court convicts a person of an offence in respect of which any law prescribes a minimum sentence, the court may in its discretion pass sentence but order the operation of part thereof to be suspended for a period not exceeding five years on any condition referred to in paragraph (a)(i) of subsection (1)".

Terblanche comments that this remedy as a condition of correctional supervision is underutilized. He states:

"Compensation is a valuable aid to victims of crime, and it involves the victim as a member of society in a process which is to the advantage of the victim. It is also an important aspect of restorative justice, in that the State assists, through the sentence of correctional supervision, the victim in securing the
deserved compensation".

Although crime victims are in terms of the law allowed to seek compensation during criminal trials, prosecutors often fail to alert them to this opportunity, thereby denying them the benefits they are otherwise entitled to. This is justice denied for crime victims.

\footnotetext{
53 S v Shilubane 20081 SACR 295 (T).

5451 of 1977.

55 Terblanche Guide to Sentencing in South Africa (2007) 298.
} 


\section{CASES FROM SOUTH AFRICA}

\section{Introduction}

Following upon recommendations by the South African Law Reform Commission, then the South African Law Commission, ${ }^{56}$ restorative justice processes were introduced into the country's criminal justice system. The recommendations related to compensation for crime victims, the introduction of victim-impact statements, victim-offender mediation, greater consultation between crime victims and the prosecution, rights for victims and the treatment of crime victims. These proposals were a direct invitation to the country to introduce restorative justice processes into our justice system. The response to these proposals was lukewarm, if not cautious, perhaps because of our system being essentially adversarial.

The South African Service Charter for Victims of Crime (the Charter) was introduced partly as a consequence of the above proposals and the universal trend to give crime victims some measure of recognition within the criminal justice system. ${ }^{57}$ However, the Charter does not provide for rights that are legally enforceable. The rights include:

(i) The right to be treated with fairness;

(ii) the right to offer information;

(iii) the right to receive information;

(iv) the right to protection;

(v) the right to compensation; and

(vi) the right to restitution.

These "rights" can only be described as aspirational ${ }^{58}$ rather than real, because they create values to which everyone should aspire. Victims cannot enforce these basic rights; they are as a result denied justice to which they should be entitled. ${ }^{59}$ Offenders, on the other hand, benefit from these shortcomings. The State has, nevertheless, created structures to support victims' needs. ${ }^{60}$ These include the creation of child and witness facilities, the establishment of Sexual Offences courts and a unit for family violence, child protection and sexual offences. These structures require one of the parties to be a child. ${ }^{61}$

56 See South African Law Reform Commission Discussion Paper 91 Sentencing: A New Sentencing Framework (2000) par 1.14.

57 In the past crime victims played a marginal role as witnesses for the State.

58 Govender "Giving Power to Victims of Crime" $20071 \mathrm{http}: / /$ www.southafrica. info/services/rights/victimscharter-launch.htm (accessed 2012-05-11).

59 Kelly "Victims" 1987 34(1) Wayne LR 80, remarks that "providing rights without remedies would result in the worst of consequences, such as feelings of helplessness, lack of control and further victimisation ... with victims in mind, it is better to confer no rights than rights without remedies".

60 In South Africa the Restorative Justice Centre was established in Pretoria about ten years ago, with the very aim of promoting a restorative approach to crime.

61 See the Child Justice Act 75 of 2008. 


\section{South African legislation}

South Africa has taken steps to provide protection of crime victims and offenders. For example, the Probation Services Amendment Act ${ }^{62}$ was enacted to cater for restorative processes. In section 1, the Act defines restorative justice as "the promotion of reconciliation, restitution and responsibility through the involvement of a child, the child's parent, the child's family members, victims and communities". ${ }^{63}$ The child referred to here is the offending child, not the child victim. This provision reserves restorative processes for child offenders, and excludes adult offenders from the process. It also does not cater for instances where the child is a victim and the offender an adult.

The South African Law Reform Commission ${ }^{64}$ had earlier defined restorative justice more flexibly as:

"[A] consideration of the involvement of crime victims in the criminal justice process, reparation to victims and community involvement in the fight against crime, and healing of the community while at the same time holding the offender accountable for his actions".

Although this definition is wide enough to include both young and adult offenders and victims, the recommendations were never implemented by the legislature, and to this extent they bring no benefits for crime victims.

The Children's Act ${ }^{65}$ provides for restorative justice processes for children. As most experts consider these processes to be necessary for child offenders, they will not be discussed here. The author is concerned with adult offenders and crime victims who seem to be enjoying very limited benefits from restorative justice processes.

\section{South African case law}

Restorative justice, it has been held, is not suitable for certain kinds of offences because of their serious nature. ${ }^{66}$ Also, some offenders, including habitual criminals, are not always suitable candidates for restorative justice. $^{67}$ Public policy would be offended if serious offences, such as rape, qualified for restorative justice processes. Adult offenders who would be considered for rehabilitation may perhaps be candidates for restorative justice processes, provided the offences they committed do not fall under serious crimes. In the rare cases involving adult offenders, restorative

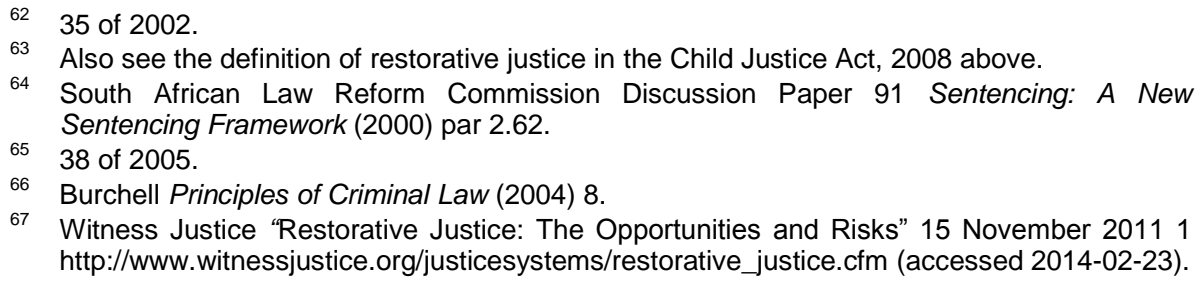

67 Witness Justice "Restorative Justice: The Opportunities and Risks" 15 November 20111 http://www.witnessjustice.org/justicesystems/restorative_justice.cfm (accessed 2014-02-23). 
processes are usually implemented during or after a criminal trial, ${ }^{68}$ where the presiding officer may allow for resolution of the dispute by parties themselves, or sentence the offender to correctional supervision. ${ }^{69}$ Demonstration by the offender of remorse or willingness to reform may influence the court to provide for restorative justice processes.

It is perhaps the pettiness of the crime that makes the victim willing to participate in, for example, family-group conferencing or other restorative processes. It is also the pettiness of the crime that enables the court to allow for the resolution of the dispute by the parties.

Although the number is gradually increasing, there are still a few cases in South Africa in which restorative justice has been applied. These few cases are relied upon to explain the rationale of the courts in relation to restorative justice. In $S \vee$ Maluleke, ${ }^{70}$ for example, the court conceded that restorative justice "cannot ensure that society is protected against offenders who have no wish to reform and who continue to endanger communities". That its application is so limited is disconcerting, considering that the focus of any country is on controlling the commission of contact crimes such as murder and rape. These are the crimes where restorative processes ought to be applied.

Restorative justice should be seen as an approach that complements retributive justice; in other words, an approach that can be used for some cases, and not others. A flexible approach is, therefore, advocated. The court in $S \vee$ Shariwa $^{71}$ remarked that "the most important factors in determining sentence are the person, the character and circumstances of the crime".

Restorative justice fits criminals who in all probability would be sentenced to short-term imprisonment, if at all, as well as those who qualify for punishment other than imprisonment, or imprisonment of approximately two years or less. It is more effective for young offenders, as well as first-time adult offenders who committed less serious crimes. As $\mathrm{Neser}^{73}$ explains: "Restorative justice involves a more practical criminal justice system emphasising crime prevention in the early stages, protecting society and relying on imprisonment as a last resort" (my emphasis). It makes no sense, therefore, to argue about recidivism, as potential recidivists are unlikely to undergo restorative justice processes anyway. If the application of restorative processes is limited to the cases described above, where does this leave the victim who yearns for protection against murderers and rapists?

68 This is with the exception of victim-impact statements which may be allowed before sentencing takes place.

69 Correctional supervision is a classic example of a sentence in which both restorative and retributive elements can be found.

$20081 \operatorname{SACR}(\mathrm{T})$.

2003 JOL $11015(\mathrm{ZH})$.

Author's own emphasis.

73 Neser "Major Movements in the Criminal Justice Field at the End of the $20^{\text {th }}$ Century" 2000 13 Acta Criminologica 1. 
Restorative justice does not often lend itself to be considered in regard to serious crimes, and can have no effect on habitual criminals and recidivists. It can, therefore, never enjoy an exclusive foothold on any criminal justice system. It is self-limiting. To be effective, it will always be applied to specific types of crimes and persons, depending on the circumstances. Burchell is correct to argue:

"[l]f restorative justice does gain a significant foothold in a criminal justice process essentially based on retributive justice, [as ours] this will possibly be in the context of youth crime and less serious infringements of criminal law, rather than in the context of serious criminal behaviour, and the implementation of various forms of punishment".

The truth of the above statement is clear from the case of $S v$ Shilubane, ${ }^{75}$ where the accused was convicted for the theft of seven fowls which the accused admitted to have cooked. Theft is theft, no matter the nature of the object stolen. The court a quo, as a result, sentenced the accused to direct imprisonment. On appeal the court stated:

"I have little doubt in my mind that, in line with the new philosophy of restorative justice, the complainant would have been more pleased to receive compensation for his loss. An order of compensation, coupled with a suspended sentence would, in my view, have satisfied the basic triad and the primary purpose of punishment. Unless presiding officers become innovative and proactive in opting for other sentences to direct imprisonment, we will not be able to overcome overcrowding in our prisons ... there is abundant evidence that retributive justice has failed. It is, furthermore counterproductive, if not self-defeating, in my view, to expose the accused like this one, in casu, to the corrosive and brutalising effect of prison life for such a trifling offence".

It is not necessary to analyse the whole extract. The court ruled that for less serious crimes imprisonment is not appropriate. We all agree. The court further noted that retributive justice has failed in that it does not lead to a reduction of crime. However, the very punishment the court imposed, humane as it may be, was nevertheless based on retribution.

\section{CONCRETE CASES OF RESTORATIVE PROCESSES IN BRIEF}

While a lot is said about the virtues of restorative justice, there is no doubt that offenders, and not crime victims, are at the centre of the programme. The process keeps most offenders out of prison; those that are in prison are well looked after in terms of facilities. There are areas, however, where victims enjoy very limited recognition, as discussed below:

\footnotetext{
Burchell Principles of Criminal Law 33.

2008 (1) SACR (T).

lbid.
} 


\section{Victim-offender mediation}

Victim-offender mediation is a process that "provides interested victims (primarily those of property crimes and minor assaults) the opportunity to meet their offenders in a safe and structured setting". ${ }^{77}$ It facilitates victimoffender interaction, and enables the victim to tell the offender how the offence affected him/her (the victim). It creates an opportunity for victims to express their feelings about the crime. ${ }^{78}$ Mediation involves a meeting with the victim, the offender and a neutral facilitator to work out an acceptable agreement in order to restore the balance that was disturbed by the offence. The outcome may be an apology, compensation or restitution by the offender and forgiveness or healing for the victim. ${ }^{79}$ Mediation affords the offender the opportunity to express remorse and to appreciate the affect of his/her conduct on the victim. ${ }^{80}$

There are clear benefits from victim-offender mediation, both for the victim and the offender, when it is employed. It results in fewer cases going to court, resulting in fewer offenders going to prison. Other benefits are the following:

(a) The victim may receive compensation as opposed to a fine; the latter usually accrues to the State;

(b) mediation may result in healing for the victim, as well as reduced anger, grief, bitterness and fear for revictimisation; ${ }^{81}$ and

(c) the offender takes responsibility for his/her actions. Chances of reoffending are reduced.

The unfortunate aspect is that these benefits are not enjoyed by most victims, ${ }^{83}$ as the beneficiaries of the mediation project are juvenile offenders who are diverted from the court processes. ${ }^{84}$ Furthermore, few offenders are arrested, resulting in an even smaller number of offenders who will be diverted away from the courts. Worse still, there is inadequate commitment

77 US Department of Justice Guidelines for Victim-Sensitive Victim-Offender Mediation: Restorative Justice Through Dialogue - A National Perspective (2007) 1.

78 Ibid.

79 According to Consedine and Bowen Restorative Justice: Contemporary Themes and Practices (1999) 62, forgiveness is "a process of the victim letting go of anger and pain of injustice so that he or she can resume, freed from the power of violation".

80 Zehr Changing Lenses: A New Focus for Crime Victims (1986) 53.

81 Morris and Maxwell Restorative Justice for Juveniles: Conferencing, Mediation and Circles (2001) 269.

82 It has been reported that South Africa has a recidivism rate of $94 \%$ of all those that were released.

83 Meintjies-Van der Walt "Towards Victim Empowerment Strategies in the Criminal Justice Process" 199811 SACJ 157 168, argues that mediation does not serve victim interests. It is a strategy based on the "assumption that participation will satisfy the needs of victims, but this is not necessarily so ..."

84 NICRO on its first victim-offender mediation project lamented the reluctance of South African prosecutors to refer serious cases to the project. It also noted that most of those that were so referred were juvenile offenders, as opposed to adult offenders. See Bazamore and Walgrave Restorative Justice for Juveniles (1999) 20. 
in this country to apply restorative processes, resulting in most victims being denied justice.

That restorative justice may be appropriate for minor crimes, a concession Burchell also made, ${ }^{85}$ indicates that the process has limitations, and cannot be applied where it would matter most for crime victims, namely, in very serious crimes, such as rape, robbery or murder. Even when it is used for serious crimes, there are clear indications that the punitive aspect is predominant in the minds of the police, prosecutors and presiding officers. Milietyiem remarks in her research that the police and prosecutors felt that mediation is suitable for minor offences such as petty theft, malicious injury to property and for offences committed by juveniles, ${ }^{86}$ and not for serious crimes. $^{87}$

\section{Family-group conferencing}

Family-group conferencing was first introduced in South Africa in 1995 through a project in Wynberg, Cape Town. This was followed by an interMinisterial Committee of another project in Pretoria. Family-group conferencing has now been incorporated into legislation ${ }^{88}$ as an acceptable practice.

Family-group conferencing follows the same principles as with mediation. However, it involves a larger group as it may include the offender and the victim, their families or representatives and a facilitator who is often a probation officer. The holding of a family-group conference can be used as a form of diversion for young offenders, but can also be a condition attached to the sentence of community corrections. ${ }^{89}$

The same benefits that victim-offender mediation provides for victims and offenders are found in cases of family-group conferencing.

\section{Victim-impact statements}

Victim-impact statements ${ }^{90}$ fulfil the Charter requirement that victims are entitled to provide information to the court. An attempt is made to put the

85 Burchell Principles of Criminal Law 33.

86 Milietyiem "Crime and Mediation (Publication No. 167)" 20001 http://www.optula.om. fi/4920.htm (accessed 2013-01-13).

87 Some writers consider the restorative model to be appropriate for serious crimes as well. See O'Connell Restorative Justice for Serious Crimes Paper Presented at the Restorative and Community Justice: Inspiring the Future Conference, Winchester, England, 28-31 March 2001.

88 See s 3 of the Probation Services Act 11 of 1991 as amended by $\mathrm{s} 2(\mathrm{k})$ of the Probation Services Amendment Act 35 of 2002; s 48 of the Child Justice Act 75 of 2008; and s 52 of the Correctional Services Act 111 of 1998.

89 See s 52(g) of the Correctional Services Act. Also see s 297 of the Criminal Procedure Act which permits suspension of sentence under specified conditions, including compensation of the victim and rehabilitation of the offender.

90 Erez "Victim Impact Statements" in Grabowsky (ed) Trends and Issues in Criminal Justice (1991) 2, defines a victim-impact statement as an organized and structured method of 
victim and his/her interests at the centre of the criminal process. Allowing for victim-impact statements was a response to calls by, among others, Naudé - that victims should be allowed to inform the court of the impact the offence had on them. ${ }^{91}$ The call was followed by the introduction of the Charter which, unfortunately, does not place a duty on anyone to do anything. The Charter also fails to provide remedies if its provisions are violated. ${ }^{92}$ This is a flaw that requires legislative intervention.

Although victim-impact statements can be made at various stages of the proceedings, the information is even more useful when the accused has been convicted but not yet sentenced. ${ }^{93}$ Schuster remarks that the influence of these statements is not on the sentence length or disposition; rather, it is on their "helping victims to reach emotional closure, bringing the humanity and reality of the victim into the courtroom, educating the court, defendant and observers about the crime's personal toll ..." ${ }^{\prime 4}$ It helps the court to have a clear picture of events, and to arrive at a balanced decision concerning the sentence.

Victim-impact statements have strong critics. ${ }^{95}$ It is submitted that the illusion is created that victims have a role to play in the sentencing of offenders, which in fact is not the case. According to Rubel, the effectiveness of sentencing will be increased if crime victims convey their feelings. The statements, if allowed, "would make the process more democratic and reflective of the community's response to crime". ${ }^{96}$

The formal acceptance and strengthening of the use of victim-impact statements in this country's legal system are recommended. It would ensure that crime victims, whose voices remain unheard most of the time, get the opportunity to express themselves. It would be the best weapon in the hands of victims if these statements were enforced in our justice system.

\section{$6 \quad$ CONCLUSION}

The author has attended courts proceedings on many occasions, and maintains that there is inadequate ${ }^{97}$ application of restorative processes by the courts. ${ }^{98}$ Restorative justice is much talked about in academic circles.

ensuring that the court is aware of important information concerning the effect on the victim that the crime has had.

91 Naudé "An International Perspective on Victim Participation in the Criminal Justice Process with Specific Reference to Victim Impact Statements" November 1995 Watch Post 69-73.

92 See Kelly 1987 34(1) Wayne LR 74.

93 These statements "are, however, not intended to influence, but to inform [the court], so that a balanced decision that takes into account the interests of both the offender and the victim is arrived at". See Makiwane "Victim Impact Statements at the Sentencing Stage - Giving Crime Victims a Voice" 201031 Obiter 613.

94 Schuster "Victim Impact Statements - Do They Make a Difference?" 200614 Watch Post 1.

95 Eg, Dubber Victims in the War on Crime: The Use and Abuse of Victims' Rights (2002) 336.

96 Rubel "Victim-Participation in Sentencing Proceedings" 198628 Criminal Law Quarterly 226 237.

97 Cf Von Bonde "Restorative Justice: Bringing Back the Pillory" 20081 SACR 133 139, who notes that restorative justice is "firmly rooted in the South African Legal system".

98 Also, see comment by Skelton 2007 Acta Juridica 235. 
Sadly, the enthusiasm displayed by researchers and academics about this newly-found solution to existing crime problems does not translate into practice, especially in the courts, where it matters most. There are many virtues in the use of restorative processes. The following limitations, however, inhibit the development of restorative justice in this country:

(i) The rights contained in the South African Service Charter for Victims of Crime are unenforceable;

(ii) the focus is mainly on child offenders and child victims; and

(iii) adult victims rarely enjoy protection. ${ }^{99}$ Offenders, on the other hand, enjoy due-process rights.

The reluctance by prosecutors, the police and the courts to implement restorative processes further inhibits the development of restorative justice. Legislative provisions that are already in place are under-utilized. ${ }^{100}$ There is a clear bias of the country's legislation towards child offenders.

It is recommended that, to empower crime victims, law enforcement agencies and social workers are encouraged to use restorative justice processes more often. The Charter for Victims of Crime should be legislated so that rights contained therein can be enforced by crime victims. While the nature of the crime, the offender and the circumstances under which the crime was committed are relevant, restorative justice should apply to all crimes for which it is appropriate, including serious crimes committed by adults. Crime victims yearn for justice; law enforcement agents and Government ought to listen.

9 Except in matters involving family violence and sex-related crimes.

100 Terblanche Guide to Sentencing in South Africa 298.

101 Both the Child Justice Act 75 of 2008 and the Probation Services Act 111 of 1991, as amended by Act 35 of 2002, provide that one of the parties to mediation, conciliation, conferencing and sentencing must be a child. 